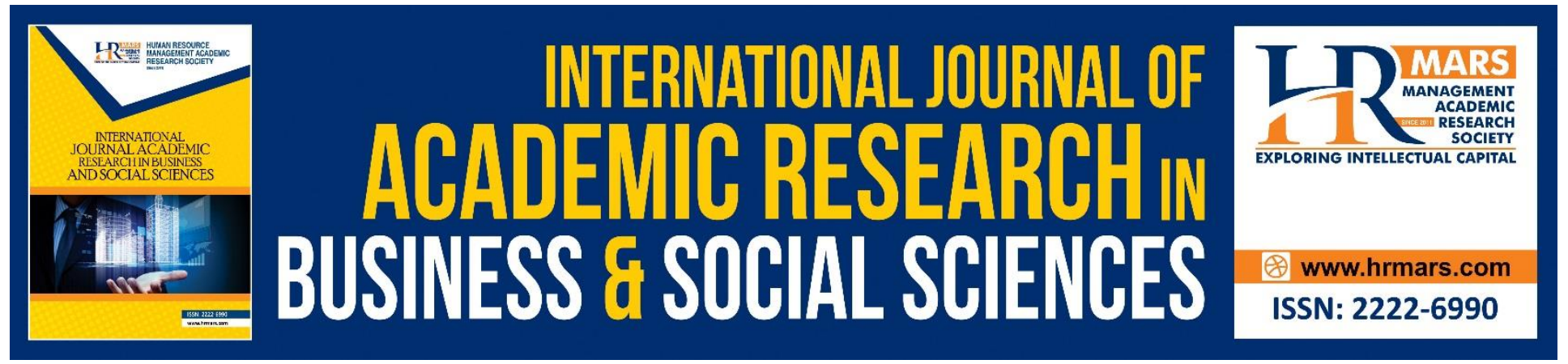

\title{
Labor Market and Economic Wage in Thailand
}

\section{Pichit prapinit, Areevan bungkerd, Mustakim Melan}

To Link this Article: http://dx.doi.org/10.6007/IJARBSS/v9-i6/5979

DOI: $10.6007 /$ IJARBSS/v9-i6/5979

Received: 10 April 2019, Revised: 19 May 2019, Accepted: 02 June 2019

Published Online: 23 June 2019

In-Text Citation: (Prapinit, Bungkerd, \& Melan, 2019)

To Cite this Article: Prapinit, P., Bungkerd, A., \& Melan, M. (2019). Labor Market and Economic Wage in Thailand. International Journal of Academic Research in Business and Social Sciences, 9(6), 653-663.

Copyright: (C) 2019 The Author(s)

Published by Human Resource Management Academic Research Society (www.hrmars.com)

This article is published under the Creative Commons Attribution (CC BY 4.0) license. Anyone may reproduce, distribute, translate and create derivative works of this article (for both commercial and non-commercial purposes), subject to full attribution to the original publication and authors. The full terms of this license may be seen at: http://creativecommons.org/licences/by/4.0/legalcode

Vol. 9, No. 6, 2019, Pg. 653 - 663

Full Terms \& Conditions of access and use can be found at http://hrmars.com/index.php/pages/detail/publication-ethics 


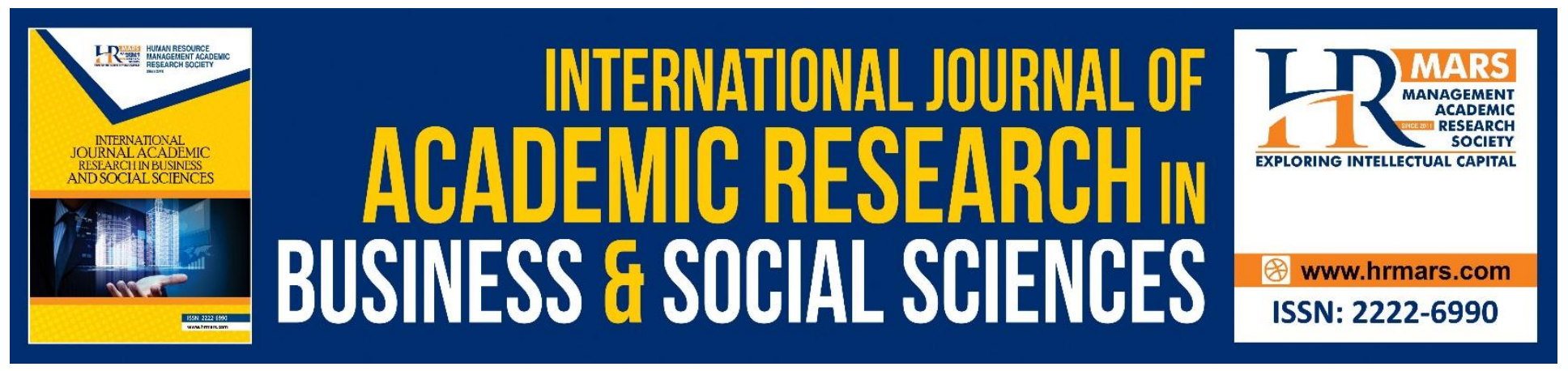

\title{
Labor Market and Economic Wage in Thailand
}

\author{
${ }^{1}$ Pichit Prapinit, ${ }^{2}$ Areevan bungkerd, ${ }^{3}$ Mustakim Melan \\ ${ }^{1}$ Loei Rajabhat University, Thailand, ${ }^{2}$ Loei Rajabhat University, Thailand, ${ }^{3}$ University Utara \\ Malaysia (UUM), Malaysia
}

\begin{abstract}
The objective of this study were 1) to study the structure of the labor market and wage determination in economics, 2) To calculate the conversion price of shadow wages in order to analyze the economic value of labor. This is how the mix. Using data from every critical landscape and interviewed scholars. Officer and Office of the National Economic and Social Development Board Bank of Thailand The concept of economics at the World Bank. By creating the equation Multiple regression 9 wages overall economics. Wage Group, the eight groups from the calculation of the flexibility of the labor market The value of the increased productivity of labor or the value of marginal product of labor : VMPL and Production Function of labor and capital that market. workers in non-competitive. Labor demand (employers) have the authority to set wages higher than the supply (employees) pay lower than market economics, wages or wage should be in a competitive economy. Therefore, the Government will intervene regularly. Which affects the movement of workers from neighboring countries to work in the labor market in the country even more. The calculation of wages and market wages should be.(Wages Economist) Wages should be 403.75 and Market wage (baht / day) 266.15 for The Country, Wages should be 84.82 and Market wage (baht / day) 114.73 for Agriculture, Wages should be 803.43 and Market wage (baht / day) 304.87 for Minerals and Coal, Wages should be 553.13 and Market wage (baht / day) 229.48 for Industry, Wages should be 144.99 and Market wage (baht / day) 176.71 for Construction, Wages should be 520.27 and Market wage Market wage (baht / day) 613.28 for Transportation, Wages should be 267.844 and Market wage (baht / day) 418.30 for Electricity and water Supply, Wages should be 182.601 and Market wage (baht / day) for Transportation Commercial,Wages should be 85.032 and Market wage (baht / day) 248.55 for service group.
\end{abstract}

Keywords: Shadow Wage, Thailand Labor Market, Economic Wage, Conversion Factors Wage 


\section{Introduction}

(Monopoly Market), considering the labor market in the past to the present, found that most of the labor supply is greater than demand. The employer has the power to determine. Wages in the market (Market wage) than it affects wage workers should be (Shadow wage), the market is too low. This may not be economically justified The reason for the state to intervene in the market. This author would like the concept and calculation of wages workers should receive wages or reflect the economic value of labor (Economics wage) and in each sector. To suggest that Wages are on the market today reflect the wages that workers should be given or not. And the composition of this article: Economic concepts about finding the wages should be calculated and how to calculate the wage should be.

1. Economic concepts about finding the wages should be.

Economists believe that the concept of a competitive market with efficient use of resources as possible. Affect social welfare in place, so the charge should be workers of each category will take place at the most appropriate. It took place

under perfect competition only. It was concluded that Wages should have been (Economics wage) refers to wages that a worker should be given an appropriate amount of work to make employers value in the economy increased. This can happen only in a perfectly competitive market. If the labor market is a market where competition is completed. Wages to reflect on the most effective use of resources. That is, the employee will be paid for the work, which we can use market wages of labor cost per unit of labor. Because wages are equal to the market value of the output unit of labor (Value of Marginal Product), but if the labor market is not fully competitive market, not the market price of labor cost per unit of labor. We need to calculate the shadow price of labor with the ability to create output value of his participation in the production. By cutting ability to create output value of other inputs to produce them. Can be summarized as the following formula )Asian Development Bank-ADB, 1997, pp. 312-315)

$\mathrm{VMPL}_{L}=\mathrm{MPP} L \times \mathrm{PQ}_{\mathrm{Q}}$

$$
\mathrm{EW}=\mathrm{MPP} \perp \times \mathrm{PQ}_{\mathrm{Q}}
$$

Thus, wages should be in it.

Determined

$\mathrm{EW}=\begin{aligned} & \text { Wages should be in } \\ & \text { the country. }) \text { Economics wage }(\end{aligned}$
$\mathrm{VMPL}_{\mathrm{L}}=\begin{aligned} & \text { The value of the increased } \\ & \text { productivity of labor ) value of marginal product of labor( }\end{aligned}$
$\mathrm{MPP}=\quad \begin{aligned} & \text { marginal physical product of labor } \\ & \mathrm{PQ}\end{aligned}=$ market price of the output




\section{Methodology}

The study, led by secondary 215-2018 years from the relevant authorities such as the Bank of Thailand. Office of the National Economic and Social Development Board National Statistical Office And the Ministry of Labor to create a multiple regression equation, and in-depth interviews with experts from the World Bank, 30 using the following equation. For the wages should be The concept of economics on wages that should have been. Which took place under perfect competition. Will start looking up for MPPL production function (production function) of each product.

\section{From}

$\mathrm{Q}=\mathrm{f}(\mathrm{K}, \mathrm{L})$

by $\quad$ Cobb - Douglas Production Function

$\mathrm{Q}=\quad \mathrm{AK}^{\mathrm{a}} \mathrm{L}^{\mathrm{b}}$

so that

$\mathrm{MPP}_{L}=\frac{\partial \mathrm{Q}}{\partial \mathrm{L}}=\mathrm{bAK}^{a} \mathrm{~L}^{b-1}$

Change it to function in a straight line to the logarithm of the variable coefficients. Can be written as $\ln Q=\ln \left(A K^{a} L^{b}\right)$

$\ln Q=\ln A+\ln K^{a}+\ln L^{b}$

$\ln Q=A^{*}+a \ln K+b \ln L$

A partial derivative with $\mathrm{L}$

$\frac{1}{Q} \frac{\partial \mathrm{Q}}{\partial \mathrm{L}}=\frac{\mathrm{b}}{\mathrm{L}} \frac{\partial \mathrm{L}}{\partial \mathrm{L}}=\frac{\mathrm{b}}{\mathrm{L}}$

$\frac{\partial \mathrm{Q}}{\partial \mathrm{L}}=\mathrm{b} \frac{\mathrm{Q}}{\mathrm{L}}$

the principle

$\mathrm{MPP}_{L}=\frac{\partial \mathrm{Q}}{\partial \mathrm{L}}$

In the study, a $Q$ value of domestic products, not production units so.

$\mathrm{VMP}_{L}=\quad \frac{\partial \mathrm{Q}}{\partial \mathrm{L}}=\mathrm{b} \frac{\mathrm{Q}}{\mathrm{L}}$. 
To find the wages of workers in the United States and should be divided into 8 groups of workers divided by the labor force survey data for the annual National Bureau of Statistics. Thus creating an equation to estimate the coefficients (b) of the Labor (L) 9 has the following equation.

The yield of the equation

$\begin{array}{lll}Q & =f(K, L) \ldots \ldots \ldots \ldots \ldots \ldots \ldots . .(3) \\ \ln Q & =A^{*}+a \ln K+b \ln L\end{array}$

Determined

$\mathrm{Q}=$ Total value of domestic products (GDP)at1988prices(billion baht).

$\mathrm{L}=$ Total number of workers (in thousands).

$\mathrm{K}=$ Stock of equity (net capital stock) at 1988 prices (billion baht).

Equation productivity in agriculture

$\mathrm{Q}_{A G}=\mathrm{f}\left(\mathrm{K}_{A G}, \mathrm{~L}_{A G}\right)$

$\ln \mathrm{Q}_{A G}=\mathrm{A}^{*}+\mathrm{a} \ln \mathrm{K}_{\mathrm{AG}}+\mathrm{b} \ln \mathrm{L}_{\mathrm{AG}}$

Determined

$\mathrm{Q}_{A G}=$ Agricultural products are valued

at current prices in 1988, the agricultural sector (billion baht).

$\mathrm{L}_{A G}=$ Total number of workers thousands).

$\mathrm{K}_{A G}=\begin{gathered}\text { Stock } \\ \text { stock }\end{gathered}$ of equity (net capital Agriculture Branchat1988 prices (billion baht).

The output of the mining branch

$Q_{\text {Min }}=f\left(K_{\text {Min }}, L_{\text {Min }}\right)$

$\ln \mathrm{Q}_{\text {Min }}=\mathrm{A}^{*}+\mathrm{a} \ln \mathrm{K}_{\text {Min }}+\mathrm{b} \ln \mathrm{L}_{\text {Min }}$

Determined

$Q_{\text {Min }}=$ The value of mining products at 1988 prices (billion baht).

$\mathrm{L}_{\text {Min }}=$ Total number

of

workers

(in thousands) 
INTERNATIONAL JOURNAL OF ACADEMIC RESEARCH IN BUSINESS AND SOCIAL SCIENCES

Vol. 9, No. 6, June, 2019, E-ISSN: 2222-6990 @ 2019 HRMARS

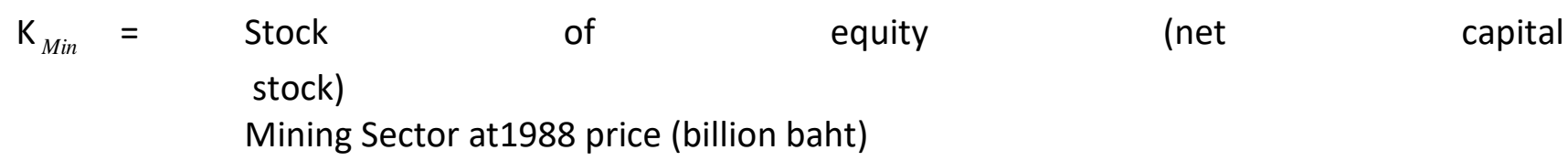

Industrial Output Equation

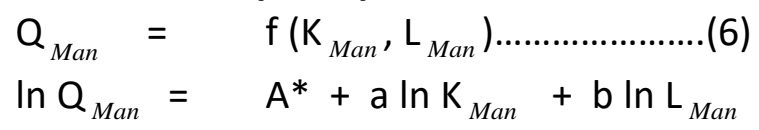

Determined

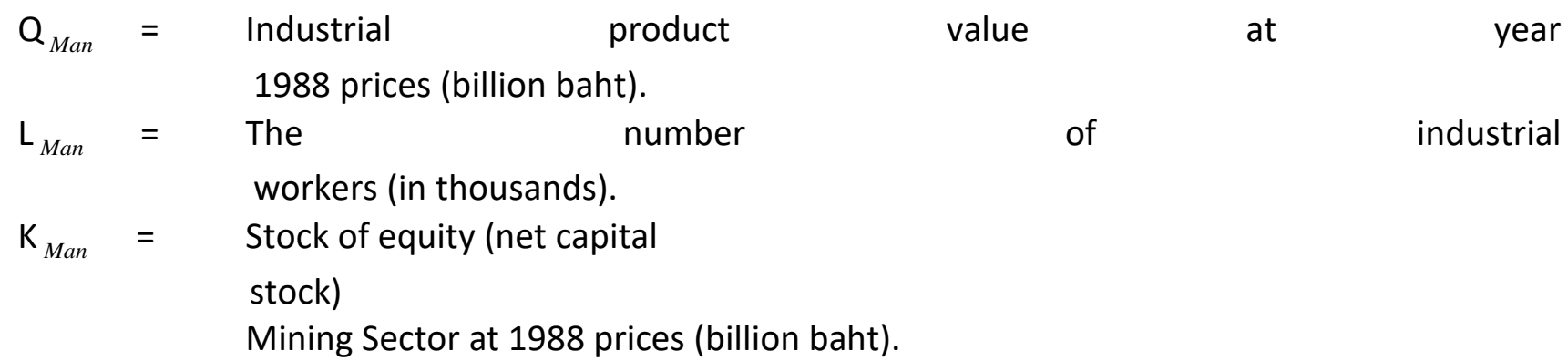

The output of the construction field

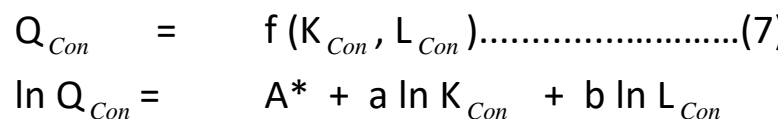

Determined

$\mathrm{Q}_{\text {Con }}=\quad$ Product value, at 1988 prices,

the construction field (billion

baht).

$\mathrm{L}_{\text {Con }}=$ The number of workers in construction (in thousands).

$\mathrm{K}_{\text {Con }}=$ Stock of equity (net capital

stock) as of year 1988 the

construction field (billion baht).

The output of electricity, gas and water.

$\mathrm{Q}_{\text {Elec }}=\mathrm{f}\left(\mathrm{K}_{\text {Elec }}, \mathrm{L}_{\text {Elec }}\right)$

$\ln \mathrm{Q}_{\text {Elec }}=\mathrm{A}^{*}+\mathrm{a} \ln \mathrm{K}_{\text {Elec }}+\mathrm{b} \ln \mathrm{L}_{\text {Elec }}$

Determined

$\mathrm{Q}_{\text {Elec }}=\quad$ Value at current prices in 1988,

the field Of electricity,gas and water (billion baht).

$\mathrm{L}_{\text {Elec }}=$ The number of workers in the electric, gas and water 


\author{
(in thousands). \\ $\mathrm{K}_{\text {Elec }}=$ Stock of equity (net capital \\ stock) at \\ current prices in 1988, electricity, gas and water (billion baht).
}

The Branches of Commercial Production.

$\mathrm{Q}_{\text {Com }}$
$\ln \mathrm{Q}_{\mathrm{Com}}=\quad \mathrm{f}\left(\mathrm{K}_{\mathrm{Com}}, \mathrm{L}_{\mathrm{Com}}\right) \ldots \ldots \ldots \ldots . . .(9)$
$\mathrm{A}^{*}+\mathrm{a} \ln \mathrm{K}_{\mathrm{Com}}+\mathrm{b} \ln \mathrm{L}_{\mathrm{Com}}$

Determined

$\mathrm{Q}_{\text {Com }}=\quad$ Value at current prices in 1988, the commercial branch (billion baht).

$\mathrm{L}_{\text {Com }}=\quad$ The number of workers in commerce (in thousands).

$\mathrm{K}_{\text {Com }}=\quad$ Stock of equity (net capital stock) as of year 1988 commercial branches (billion baht).

The equation yields the field of transport, warehousing and communications.

$$
\begin{aligned}
& \mathrm{Q}_{\text {Tran }}=\mathrm{f}\left(\mathrm{K}_{\text {Tran }}, \mathrm{L}_{\text {Tran }}\right) \\
& \ln \mathrm{Q}_{\text {Tran }}=\mathrm{A}^{*}+\mathrm{a} \ln \mathrm{K}_{\text {Tran }}+\mathrm{b} \ln \mathrm{L}_{\text {Tran }}
\end{aligned}
$$

Determined

$$
\begin{array}{ll}
\mathrm{Q}_{\text {Tran }}= & \begin{array}{l}
\text { Value at current prices in 1988, } \\
\text { the field of transport (billion } \\
\text { baht) } .
\end{array} \\
\mathrm{L}_{\text {Tran }}= & \begin{array}{l}
\text { The number of transport } \\
\text { workers (in thousands). }
\end{array} \\
\mathrm{K}_{\operatorname{Tran}}= & \begin{array}{l}
\text { Stock of equity (net capital } \\
\text { stock) at current prices in 1988, } \\
\text { the field of transport (billion } \\
\text { baht). }
\end{array}
\end{array}
$$

Equation Branch Productivity Services

$$
\begin{aligned}
& \mathrm{Q}_{\text {Ser }}=\mathrm{f}\left(\mathrm{K}_{\mathrm{Ser}}, \mathrm{L}_{\mathrm{Ser}}\right) \\
& \ln Q_{S e r}=A^{*}+a \ln K_{S e r}+b \ln L_{S e r}
\end{aligned}
$$


Determined

$\mathrm{Q}_{\text {Ser }}=\quad$ Value at current prices in 1988, service sector (billion baht).

$\mathrm{L}_{\text {Ser }} \quad=\quad$ Labor service branch (thousand).

$\mathrm{K}_{\text {Ser }} \quad=\quad$ Stock of equity (net capital stock) as of year 1988, service sector (billion baht).

The results of the equation from the equation will be 3 to 11 , and the parameter $b$ part $\bar{Q}$ and $\overline{\mathrm{L}}$ determined from the average of the data to the equation below.

$$
\operatorname{VMP}_{L}=\quad \frac{\partial \mathrm{Q}}{\partial \mathrm{L}}=\mathrm{b} \frac{\overline{\mathrm{Q}}}{\overline{\mathrm{L}}}
$$

Has VMPL is the wages of workers should be. In the field of production of 8 branches, each branch.

\section{Result and Discussion}

1. The Results of the labor market

Results of the analysis showed that demand for labor in the labor market (employers) are mostly private. Have the power to negotiate higher wages than the supply (of employees) is the largest labor market. The labor market in the agricultural sector, followed by the industrial market. And markets in the service sector is growing rapidly as a restaurant. Business Financial Services Business services, logistics. The market is often a market monopoly. The labor market in services. This is consistent with studies of the World Bank in 2002 and 2009. Thus, the Bank of Thailand to intervene in the market to help workers in Thailand

2. The calculation of wages should be.

The concept of economic modeling used to calculate the value of the output unit of labor (VMPL) or wage should be in the country by providing information of each variable in the equation 3-11. Estimated coefficient of labor and (b) a reasonable wage of each branch of production, as shown in the table. 
INTERNATIONAL JOURNAL OF ACADEMIC RESEARCH IN BUSINESS AND SOCIAL SCIENCES

Vol. 9, No. 6, June, 2019, E-ISSN: 2222-6990 @ 2019 HRMARS

\begin{tabular}{|c|c|c|c|c|c|c|}
\hline $\begin{array}{l}\text { (1) } \\
\text { equation }\end{array}$ & $\begin{array}{l}\text { (2) } \\
\text { Major production }\end{array}$ & $\begin{array}{l}\text { (3) } \\
\text { bor } \\
\text { Labor }\end{array}$ & $\begin{array}{l}\text { (4) } \\
\text { YIELD } \\
\text { (E) } \\
\text { (Million baht) }\end{array}$ & $\begin{array}{c}\text { (5) } \\
\text { average } \\
\text { labor } \\
\text { (I) } \\
\text { (million } \\
\text { people) }\end{array}$ & $\begin{array}{c}\text { (6) } \\
\text { Wagos } \\
\text { should be } \\
\text { (bant!) } \\
\text { day). }\end{array}$ & $\begin{array}{c}\text { (7) } \\
\text { Market } \\
\text { wage } \\
\text { (babt' } \\
\text { day)! }\end{array}$ \\
\hline 1 & The Country & 2.622 & $5,171,869.79$ & 33.59 & 403.75 & 266.15 \\
\hline 2 & Agriculture & 2.666 & $506,548.79$ & 15.92 & 84.82 & 114.73 \\
\hline 3 & Minerals and Coal & 0.330 & $117,763.29$ & 0.05 & 803.43 & 304.87 \\
\hline 4 & industry & 1.520 & $1,693,845.50$ & 4.66 & 553.13 & 229.48 \\
\hline$s$ & Construction & 1.414 & $217,513.57$ & 1.71 & 144.99 & 176.71 \\
\hline 6 & Transportation & 0.483 & $151,752.07$ & 0.14 & 520.27 & 613.28 \\
\hline 7 & Electricity and water Supply & 0.660 & $397,935.36$ & 0.98 & 267.844 & 418.30 \\
\hline 8 & Transportation Commercial & 1.019 & $832,101.64$ & 4.64 & 182.601 & 249.78 \\
\hline 9 & service & 1.479 & $271,885.00$ & 4.73 & 85.032 & 248.55 \\
\hline
\end{tabular}

Table 1: The wages that should have been paid and the labor market, broken down by sector in the country.

Source: The shadow price for the analysis of economic projects in the country. (Page 189), Pichit Prapinit, 2015, dissertation in economics. Ramkhamhaeng university.

Table 1 The calculation of the wage should be sector and another 8 branches, keeping in mind the importance of labor.Yields in Thailand By considering the $b$ value in column (3) is that the flexibility of the Employee. Productivity in When the whole country is found. When workers to one unit can affect productivity in the country. To 2.622 units Considering Sectorial production agriculture workers have a role to produce the most was 2.666, that is when workers in the field of agricultural production to one unit can affect the yield to 2.666 units and workers are vital to productivity. minimum The field of electrical supply is only 0.483 . When calculating the wages of workers should be given. Or wage economy Transformed the shadow price of labor in the country and by sector 8 production branch in column (6) found that wages should be taken of the Thailand national average of 403.75 baht, considering sector wages. workers should get the maximum. Branch coal mine and the daily average of 803.43 , followed by the industrial sector. Wages should be daily average of 553.13 baht and branches with wage labor should be lowered. Agriculture is 84.82 baht per day.

Considering the wage market (Market wage) in column (7), which was based on a survey of the National Bureau of Statistics in 2549 showed that wages in the market an average of 266.19 baht and the employment market in the field of desalination shadow price. most of the workforce is The field of electrical and plumbing equals 613.28 baht per day, followed by the field of transport 418.30 baht daily wage and branches with low-end market is agriculture 114.73 baht per day.

From the result, Shows that wage worker would earn a higher wage is happening in the market, it reflects the structure of the labor market is a market that is not perfect is the first wage market, lower wages should be. Will Show that the employer has the power to determine wages than employees in sectors such as mining and coal. industry Electricity supply And another group with wages higher than the market wage workers should be given. Shows the operator the power to determine wages than workers in agricultural fields such as construction, transportation, field service and commercial sectors. 


\section{Benefits of wages should be.}

Wages should be paid or the economy. A wage that reflects the wage that took place under perfect competition.

Believed to be the most effective use of resources. Can be used in applications in the fields below.

1. Applied to the structural analysis of the labor market each, if wages should receive equal pay market shows that the labor market itself. The labor market is complete And if there are differences, the labor market does not mean perfection. This may be due to the power of one party dominating the market rates. If wages should be higher than the market wage that. The labor market has plenty of give employers the power to set wages, the wages, the actual low. To be fair, the government intervened in the market by the prescribed minimum wage.

2. Apply to the calculation of costs and returns of actual production of goods and services by the government as public goods that is costing and return economics to analyze the value of the resource. The projects of the government.

3. To calculate the shadow price (Conversion factors) to the value that it brings to the market wage. It makes real wages. This will facilitate the analysis of economic projects in the future.

4. Applied in determining whether the government should take measures or policies to suit the characteristics of the labor market in each sector.

\section{Conclusion}

Wages should be or economics is paid wages that workers receive the equivalent value of labor makes to the lockout. Which took place under perfect competition. Sometimes called wage Shadow (Shadow wage) be used to analyze the structure of the labor market. Costs and rewards of labor economics. In analyzing the projects of the government. This can be calculated by introducing the concept of economic modeling and computation. By modeling the manufacturing sector and 8 production branch that wages should be higher than the wages of the market. show that Labor market demand in the labor market than the labor supply, namely in the remains of unskilled labor. And semi-skilled workers have plenty of opportunity to make a demand to hire more. And another one in some areas of manufacturing wages should receive lower wages in the fields such as agriculture, construction field. And field service show that Labor shortages in the market sector, these findings suggest that. Wages occurred in the labor market at present is too low compared with wages that workers should receive. So, to be fair, economic or policy measures, the state should have to pay the market higher.

\section{Acknowledgement}

Full research reports are attainable with the relevant agencies that provide funding for research is the Commission's Research Council of Thailand. And thanks The World Bank experts to heck for accuracy. Office of the National Economic and Social Development Board Bank of Thailand Ministry of Labor and Loei Rajabhat University. 
INTERNATIONAL JOURNAL OF ACADEMIC RESEARCH IN BUSINESS AND SOCIAL SCIENCES

Vol. 9, No. 6, June, 2019, E-ISSN: 2222-6990 (C) 2019 HRMARS

\section{References}

1. Pipatsithee, C. (2001). Economic Analysis. (4th edition). Bangkok: Textile and journal Public Limited. The Bank of Thailand. (2007).

2. Industrial Finance Corporation of Thailand. (1998). Economic Analysis documentation. Bangkok.: Author.

3. Boonserm, P. (2006). Analysis of development projects. Bangkok: Publisher Ramkhamhaeng University

4. Tongyingsiri, P. (1999). The planning and project analysis. Bangkok: SE-ED applications.

5. Prapinit, P. (2015). Shadow wage for the analysis of economic projects in the country. Dissertation in economics, University .

6. Prapinit, P. (2009). Shadow price for the analysis of economic projects in the country. Dissertation in economics, University Office of the National Economic and Social Development Board (2538). Documentation Project economics: Author.

7. National Statistical Office. (2016). Report of the situation of the working population of the Kingdom. Bangkok: Author.

8. National Statistical Office. (2006). Report of the situation of the working population of the Kingdom. Bangkok: Author

9. Appleyard, D. R. (2000). International Economics. (3rd ed.) Boston: Irwin/McGraw-Hill.

10. Asian Development Bank (ADB). (2003). Guidelines for the Economic Analysis of Projects. Washington, D.C.: Author.

11. Ahmed, S. (1983). Shadow Prices for Economic Appraisal of Projects : An Application to Thailand. World Bank Staff Working Paper, No. 609. Bangkok Thailand: The World Bank.

12. Dreze, J., \& Stern, N. (1988). Policy Reform. Shadow Prices, and Market Prices. World Bank Staff Working Paper No. 450. Washington, D.C.: Economic Development Institute of the World Bank. http://EconPapers.repec.org/RePEc:wbk:wbrwps:479

13. International Money Fund (2005). World Economic Outlook Databases. Retrieved November 20, 1998 from http://www.imf.org/external/ns/cs.aspx?id=28

14. Phillips, D. A. (1989). Economic Development, Assumption of Accounting Prices and Their Application to Economic and Distributional Analysis of the Choice of Technology in Nepal Textile

15. World Bank. (2002). International Bank for Reconstruction and Development. Retrieved October 10, 2008, from http://www.wber.oupjournals.org/cgi/content/abstract/16/1/1 